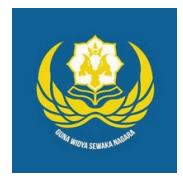

Jurnal Analogi Hukum

Journal Homepage: https://ejournal.warmadewa.ac.id/index.php/analogihukum

\title{
Kedudukan Wanita Dalam Mewaris Setelah Adanya Keputusan Pesamuhan Agung III Majelis Utama Desa Pakraman Bali (Nomor o1/KEP/PSM-3/MDP Bali/X/2010)
}

\author{
Ni Putu Indah Pratiwi*, Diah Gayatri Sudibya dan Ni Made Sukaryati Karma \\ Universitas Warmadewa, Denpasar-Bali, Indonesia \\ *indahpratiwi@gmail.com
}

\begin{abstract}
How To Cite:
Pratiwi, N. P. I., Sudibya, D. G., \& Karma, N. M. S. (2021). Visum Kedudukan Wanita Dalam Mewaris Setelah Adanya Keputusan Pesamuhan Agung III Majelis Utama Desa Pakraman Bali (Nomor 01/KEP/PSM-3/MDP Bali/X/2010). Jurnal Analogi Hukum. 3(1). 116-121. Doi: https://doi.org/10.22225/ah.3.1.3033.116-121

Abstract-The survival of a society is guaranteed by marriage, which there is a legal heir. The existence of legal heirs in Indonesia is still not currently legal, as well as unification of Bali from a district with other counties could not be equated the inheritance system. Bali has a fatherly line that ispatrilinial, which causes only the descendants of the kapurusa's status as heir in the family. Then with the decision of the Supreme Pesamuhan III which describes possible female heir or heirs. Formulation of the difficulty in this study is how the situation of women in Bali in Bali where the inheritance in the family embraced the system patrinial and how the position of women of Bali after the promulgation of the decision of the Supreme Pesamuhan III MUDP. The type of research used in this study is normative legal research. Thus the legal heirs in Bali customs, women cannot inherit because she is not capable in undertaking its obligations, whether liability caring for parents or an obligation in customary and ayahan temples. Whereas after the Supreme Pesamuhan III MUDP Bali said women can fully inheriting like male although in that women marrying out but he had to keep running its obligations.
\end{abstract}

Keywords: Inheritance Customary Law; Position of Women; Decision of Pesamuhan Agung

\begin{abstract}
Abstrak - Kelangsungan hidup suatu masyarakat dijamin oleh perkawinan, yang didalamnya terdapat hukum waris. Adanya hukum waris di Indonesia saat ini masih belum merupakan unifikasi hukum, begitupun di Bali dari satu kabupaten dengan kabupaten lainnya tidak dapat disamakan sistem kewarisannya. Di Bali menganut sistem patrilinial yaitu mengikuti garis kebapakan, yang menyebabkan hanya keturunan berstatus kapurusa yang menjadi pewaris dalam keluarga. Lalu dengan adanya Keputusn Pesamuhan Agung III yang menjelaskan dapatnya wanita menjadi pewaris atau ahli waris. Perumusan masalah dalam penelitian ini yaitu Bagaimana kedudukan wanita Bali dalam pewarisan yang ada di Bali dalam sistem kekeluargaannya menganut patrinial dan bagaimana kedudukan wanita Bali dengan adanya Keputusan Pesamuhan Agung III Majelis Utama Desa Pakraman Bali. Tipe penelitian yang digunakan dalam penelitian ini adalah penelitian hukum normatif. Dengan itu dalam hukum waris adat Bali wanita tidak dapat mewaris karena dianggapnya tidak mampu dalam menjalankan kewajibannya, baik kewajiban merawat orang tua ataupun kewajiban dalam ayahan adat dan pura. Sedangkan setelah adanya Pesamuhan Agung III MUDP Bali dikatakan wanita dapat mewaris secara penuh layaknya laki-laki walaupun dalam hal itu wanita kawin keluar namun ia harus tetap menjalankan kewajibannya.
\end{abstract}

Kata Kunci: Hukum Adat Waris; Kedudukan Wanita; Keputusan Pesamuhan Agung

\section{Pendahuluan}

Warga Negara ialah orang-orang bangsa asli Indonesia dan orang-orang bangsa lain yang disahkan dengan Undang-undang sebagai warga Negara serta setiap orang berhak untuk hidup serta mempertahankan hidup dan kehidupannya dengan cara membentuk keluarga dan melanjutkan keturunan melalui perkawinan yang sah sesuai Undang-undang Dasar Negara Republik Indonesia Tahun 1945. Di Indonesia khususnya di Bali mengenal hukum waris setelah adanya perkawinan yang dilangsungkan, baik mengenai harta waris gono gini ataupun 
harta bawaan dari sebelum menikah (Rato, 2015).

Diantara hukum-hukum yang ada yaitu hukum adat dan hukum waris yang memang secara substansi tidak dpat dipisahkan dengan masyarakat pada umumnya terutama di Bali lazimnya persekutuan hukum itu hidup, tumbuh dan berkembang. Hukum adat dan masyarakat diibaratkan dengan jiwa dan raga yaitu menunggal. Hukum adat merupakan produk budaya sekaligus prosuk social yang bersangkutan dengan hukum waris, yang didalamnya berisikan tentang nilai-nilai budaya sebagai hasil cipta karsa dan rasa manusia. Sedangkan dalam hukum waris berisikan tentang harta benda orang yang sudah meninggal, pemindahan kekayaan yang ditinggalkan oleh yang meninggal dan salah satu cara untuk memperoleh hak milik.

Hukum waris yang berlaku di Indonesia sampai saat ini masih belum merupakan unifikasi hukum, akibatnya sampai saat ini pengaturan masalah kewarisan di Indonesia khususnya di Bali masih belum mendapat keseragaman. Hukum waris yang dimana menjadi salah satu bidang hukum yang berada diluar bidang yang bersifat netral dirasa sulit untuk diperbaharui dengan perundang-undang atau kodifikasi guna mencapai suatu unifikasi hukum. Yang menjadi masalah atau hambatan membuat hukum waris dengan unifikasi yang baru yaitu dengan beranekaragamnya corak budaya, agama, sosial, dan adat istiadat serta system kekeluargaan yang hidup dan berkembang di dalam masyarakat Indonesia ini. Begitupun di Bali dari satu kabupaten dengan kabupaten lainnya tidak bisa disamakan sistem kewarisannya. Dari itu perkembangan hukum adat waris dipengaruhi oleh berbagai faktor sebagai pembawa pengaruh dalam perubahan hukum adatnya yang dintaranya adalah masyarakat adat Bali yang mengandung suatu hubungan keperdataan yang patrilinial yang mengikuti garis kelahiran laki-laki. Di Bali hubungan keperdataan patrilinial yang dimana hubungan mewarisnya lebih dominan pada purusa yakni laki-laki. Hal itu dikarenakan adanya kepercayaan agama Hindu dimana hanya keturunan laki-laki yang mempunyai hak lebih banyak untuk mewaris dibandingkan dengan perempuan.

Pada tahun 2010 adanya suatu keputusan yang menyatakan di Bali bahwa status sebagai wanita mempunyai hak untuk mewaris atau wanita sebagai ahli waris sebagaimana yang tertuang dalam Keputusan Pesamuhan Agung III yang ada di Bali. Dalam Keputusan Pasamuhan Agung III/2010 diputuskan mengenai kedudukan suami-istri dan anak terhadap harta pusaka dan harta gunakaya, termasuk hak waris anak perempuan dari anak kandung maupun anak angkat. Wanita menyambut baik Putusan Pesamuan Agung III, mereka merasa pantas menerima waris dari orang tuanya, alasan sama-sama sebagai anak yang patut diberikan kasih sayang dan keadilan dalam segala hal, termasuk warisan, jika ada penerimaan warisan yang beda dengan anak laki-laki, itu tidak masalah mengingat ada perbedaan tanggung jawab. Ada orang tua yang mengisahkan pemberian warisan kepada semua anak-anaknya, walaupun anak perempuannya warisan diberikan dalam bentuk paweweh perkawinan yaitu pemberian orang tua kepada anak perempuannya yang menikah sebagai modal hidup bersama dengan suaminya, memang paweweh itu tidak sama dengan yang diterima anak laki-lakinya. Kebijakan orang tua seperti itu ternyata dapat diterima oleh anak laki -lakinya.

Pada penelitian sebelumnya, (Arta, Sudiatmaka, \& Windari, 2018) mengungkapkan Keputusan Pesamuhan Agung III/2010 MUDP Bali terkait kedudukan anak perempuan Hindu Bali dalam pewarisan, karena budaya paternalistik yang sudah mengkristal sehingga Keputusan Pesamuhan Agung III/2010 MUDP Bali tersebut sulit untuk diterapkan sehingga ada ucapan "anak mule keto dini" (memang seperti itu disini).

Dari apa yang diuraikan dalam latar belakang masalah tersebut diatas, maka dapat ditemukan 2 (dua) permasalahan yang akan dibahas dalam kajian ini yaitu:

- Bagimanakah kedudukan wanita Bali dalam pewarisan yang dimana di Bali dalam sistem kekeluargaanya menganut sistem patrilinial?

- Bagaimana kedudukan wanita Bali setelah dikeluarkannya Keputusan Pesamuhan Agung III MUDP Bali?

Tujuan dari penelitian ini dibedkan menjadi dua yaitu tujuan umum dan tujuan khusus. Untuk tujuan umum adalah sebagai berikut: a) Untuk syarat dalam meraih gelar Sarjana Hukum pada Fakultas Hukum Universitas Warmadewa. b) Untuk perkembangan pengetahuan hukum adat di bidang pembagianwarisan menurut Keputusan Pesamuhan Agung III Bali. c) Melatih kemampuan dalam memahami hukum adat dan Keputusan Pesamuhan Agung III MUDP Bali.

Tujuan Khusus dari penelitian ini adalah:

- Untuk mengetahui kedudukan wanita Bali 
dalam mewaris menurut hukum adat waris Bali yang menganut sistem kekeluargaan patrilinial.

- Untuk mengetahui kedudukan wanita sebagai ahli waris dalam Keputusan Pesamuhan Agung III MUDP Bali.

\section{Metode}

Dalam memperoleh, mengumpulkan dan menganalisa bahan hukum yang bersifat ilmiah, memerlukan metode dengan tujuan agar karya ilmiah memiliki susunan yang sistematis, mtodelogis, dan konsisten. Adapun metode penelitian ini adalah sebagai berikut:

Tipe penelitian ini menggunakan tipe penelitian normative, yaitu tipe penelitian yang di dasari oleh peraturan perundang-undangan yang berlaku sesuai dengan keadaan yang ada dan pendekatan konseptual dalam masyarakat dan menggunakan pendekatan perundangundangan karena pendekatan ini dilakukan dengan menelaah peraturan yang menyangkut dengan permasalahan yang dihadapi. Penyusunan penelitian ini terdapat dua bahan hukum yang digunakan yakni:

- Bahan Hukum Primer yang bersumber dari beberapa undang-undang yang berkaitan dengan pokok permasalahan.

- Bahan Hukum Sekunder adalah sumber bahan hukum yang berasal dari library research yaitu suatu penelitian kepustakaan yang berupa buku-buku atau literature, dokumen, makalah atau jurnal dan artikel yang ada hubungannya dengan pokok masalah yang akan dikaji.

Pengumpulan bahan hukum dilakukan dengan teknik yaitu pengutipan, bahan hukum yang dikumpulkan dan mengelompokan dan menyeleksi bahan hukum yang diperoleh kemudian dihubungkan dengan, asas-asas, dan kaidah-kaidah hukum yang diperoleh dari studi kepustakaan sehingga diperoleh jawaban atas permasalahan.

Dalam penulisan penelitian ini bahan hukum yang sudah dikumpulkan dan diolah sesuai dengan kualitasnyaakan di paparkan melalui kalimat-kalimat yang menggambarkan tentang pemecahan masalah. Bahan hukum primer di analisis interprensi hukum yang sudah didapatkan disusun secara sistematis juga agar dapat memudahkan pembaca untuk memahami apa saja yang akan dibahas.

\section{Hasil dan Pembahasan}

\section{Kedudukan Wanita Bali dalam Pewarisan yang Dimana Di Bali Dalam Sistem Kekeluargaanya Menganut Sistem Patrilineal}

Dikutip dari buku Ketut Artadi, Menyer Fores mengemukakan bahwa sistem kekerabatan suatu masyarakat dapat digunakan untuk menggambarkan struktur sosial dari masyarakat yang berada dalam suatu wilayah yang memiliki peraturannya sendiri. Kekerabatan adalah suatu unit-unit sosial yang terkait berberapa keluarga yang memiliki hubungan darah atau hubungan perkawinan. Dalam hukum adat waris yang dimana sistem kekeluargaan merupakan salah satu bagian yang terpenting dalam keluarga di Bali khususnya, oleh karena itu yang penting hukum adat waris berpatokan pada susunan masyarakatnya yang dimana sistem kekeluargannya yang ada di Bali sesuai sitem turun temurunnya. Anggota kekerabatan terdiri atas ayah, ibu, anak, menantu, cucu, kakak, adik, paman, bibi, kakek, nenek dan seterunya. Ada beberapa macam kelompok kekerabatan dari yang jumlahnya relatif kecil hingga besar seperti keluarga ambilineal, klan, fatri, dan paruh masyarakat. Masyarakat umumnya juga mengenal kelompok kekerabatan lain seperti keluarga inti, luas, bilateral, dan uniteral (Artadi, 2017).

Dalam hukum adat waris masih tetap berlaku sistem patrilinial dalam mewaris di keluarga yang dimana harta waris jatuh kepada anak laki-laki atau (kebapakan) bukan anak perempuan. Para ahli berpendapat hukum adat waris masih dipengaruhi oleh prinsip garis keturunan yang berlaku dalam masing-masing masyarakat yang ada di Indonesia. Dalam buku Gede Panetje, menurut V.E. Korn dalam perspektif hukum adat Bali menyatakan bahwa hukum pewarisan adalah bagian paling sulit dari hukum adat Bali dikarenakan adanya perbedaan dibeberarapa daerah dalam wilayah hukum Bali (Desa Kala Patra), baik mengenai banyaknya barang-barang yang boleh diwariskan atau mengenai banyaknya bagian masing-masing ahli waris maupun mengenai putusan-putusan pengadilan adat (Panetje, 1995). Sistem kekeluargaan dalam hukum adat waris sangat erat kaitannya dengan masyarakat Bali yang dimana sistem kekerabatan tersebut bertitik tolak dari bentuk masyarakatnya dan sifat kekeluargaannya, dan garis keturunannya. Dalam masyarakat Bali keturunan merupakan hak yang penting untuk meneruskan garis keturunan lurus atau menyamping. Dalam sistem kekeluargaan di Indonesia ada tiga macam sifat kekeluargaan yaitu sistem patrilinial yang mengikuti garis keturunan ayah, lalu ada sitem matrilian yang mengikuti 
keturunan ibu dan sistem parental yakni bisa mengikutu garis keturunan ayah atau ibu. Di Bali masyarakatnya dalam sistem kekeluargaannya lebih cenderung menekankan kepada keturunan laki-laki dimana dalam sistem kekeluargaan patrilinial pentingnya untuk meneruskan sistem pewarisan yang bersifat material maupun immaterial. Dalam sistem pewarisan pada umumnya yang dianut masyarakat Bali ialah kepercayaan terhadap leluhur yang dimaksud adanya ikatan keperdataan antara satu orang dengan orang yang lainnya atau lebih. Tetapi masyarakat Bali dalam kenyataannya menganut sitem kekerabatan dalam berbagai macam sesuai dengan situasi dan kondisi dari desa dan wilayah yang bersangkutan serta bentuk harta dan kekayaan. Sistem kekeluargaan merupakan suatu penghubung garis keturunannya laki-laki dan anak yang lahir, yang dimana sering disebut dengan patrilinial mumi seperti yang berlaku pada masyarakat Bali.

Konsep warisan dalam hukum adat Bali memiliki perbedaan makna dengan warisan dalam pengertian hukum barat yang memiliki sifat materiil atau memiliki nilai uang. Hak mewaris yang dimiliki oleh seorang wanita di Bali biasanya diperoleh ketika anak perempuan diangkat sebagai ahli waris oleh seorang atau oleh keluarganya sendiri dengan status adat sentana rajeg. Pada Hukum adat waris Bali wanita dapat mendapatkan warisan dari orang tuanya apabila status hukum perkawinannya sebagai purusa dengan perkawinan nyeburin. Sentana Rajeg mempunyai kedudukan yang sama dan sejajar dengan anak laki-laki yang berhak mewaris yang ditetapkan oleh orangtuanya untuk meneruskan keturunan dengan perkawinan kaceburin. Sebagaimana tujuannya dilangsungkan perkawinan salah satunya adalah meneruskan keturunan di keluarganya.

Menurut Hukum Adat Waris yang ada di Bali seseorang yang melakukan sentana rajeg diperlakukan sama seperti anak kandung sendiri terhadap harta warisan dan sebaliknya si anak itu kehilangan hak warisnya di rumah keluarga sendiri dan ia berkewajiban untuk menyelenggarakan upacara semestinya yang dilakukan di rumah barunya dan di keluarga tersebut. Pada kosekuensinya seseorang yang melakukan perkawinan nyeburin disamakan dengan anak kandung sehingga kewajiban yang dipikulnya dalam keluarga adalah sama. Dan mengenai harta warisan akan dibagi sesuai dengan bagian dan kewajibannya dalam sebuah keluarga. Untuk dapat memahai seluruh aspek kewarisan maka pendekatan harus dilakukan dengan tiga hal pokok. Pokok pertama yaitu pewaris, pokok kedua adalah harta yang ditinggalkan oleh pewaris, dan yang ketiga para penerima harta warisan yang disebut dengan ahli waris (Artadi, 2017). Dengan pewarisan itu terhadap harta warisan orang tua sebagai pewaris dalam hubungan ini seharusnya berusaha untuk tidak menghabiskan sama sekali harta tersebut sebab kaitan harta warisan itu tidak selesai sampai disitu saja. Karena dilihat dari sudut hak pewaris yaitu orang tua maka akhirnya harta warisan itu harus dipakai untuk suatu amal bhakti kepada orangtua oleh anakanaknya yaitu ahli waris dengan anak-anak harus melakukan pembakaran jezanah orangtua jika telah meninggal dunia. Setidak-tidaknya mengambil biaya dari harta-harta yang di wariskan atau ditinggalkan (Panetje, 1995). Tetapi dalam hukum adat waris biasanya anak perempuan yang sudah kawin keluar akan diberikan tetata atau jiwadana atau bekal hidup sesuai kemampuan keluarganya. Dengan melihat kedudukan anak perempuan dalam hal tersebut mendapatkan suatu kebaikan yang mengakibatkan perlindungan terhadap harga diri seorang wanita. Oleh itu dengan maraknya persamaan gender tujuannya sama untuk mendapatkan hak yang sama dengan laki-laki begitu pula siap untuk menjalankan kewajibankewajiban sesuai dengan hak yang didapat.

\section{Kedudukan Wanita Bali Setelah Dikeluarkannya Keputusan Pesamuhan Agung III MUDP Bali}

Pesamuhan Agung III Majelis Utama Desa Pakraman atau MUDP adalah suatu lembaga resmi daerah non pemerintahan yang berdiri sendiri dan kedudukannya diperkuat oleh Perda Provinsi Bali Nomor 03 Tahun 2001 tentang Desa Pekraman. Dengan lembaga resmi daerah maka keputusan-keputusan yang dihasilkan MUDP bersifat mengikat seluruh Desa Pekraman Bali dan wajib mendapatkan pengamanan pelaksaan oleh seluruh instansi terkait di berbagai jenjang pemerintahn di Bali. Dalam Pesamuhan Agung III MUDP sistem pewarisan masih sama seperti sistem pewarisan pada umumnya, dan sistem kekeluargaan mewaris menurut hukum adat waris yaitu masih sama menganut sistem patrilinial yang mengikuti garis keturunan laki-laki, hanya saja dalam MUDP lebih menekankan bagaimana wanita dapat mewaris dalam keluarga atau bisa menjadi ahli waris dalam kelaurganya tersebut. Dengan adanya Keputusan Pesamuhan Agung III yang dimana dalam hal tersebut mengatur kedudukan wanita dalam mewaris yang terdapat penjelasan bagimana wanita mewaris dalam hal 
tersebut dapatnya wanita menjadi ahli waris dalam keluarganya sendiri. Karena dianggapnya dalam sebuh keluarga wanita mewaris hanya dapat harta bawaan yang itupun jika diberikan oleh keluarga dengan sukarela. Anggapannya karena wanita kawin keluarga maka dia tidak menjalankan kewajiban-kewajiban dirumahnya terdahulu, maka dari itu dari putusan Pesamuhan Agung dapat dikatakan wanita mendapat harta warisan yang tidak harus diwarisi hanya untuk anak laki-laki saja (Utari, 2008). Pada masyarakat Bali walaupun wanita yang sudah kawin keluar ternyata masih sering menjalankan kewajibannya kepada orangtuanya seperti merawatnya datang kerumah ikut membantu dalam upacara adat yang dilaksanakan dirumahnya terdahulu maka itu dirasakan wanita juga berhak mewaris (Muhammad, 2006).

Hasil Pesamuhan Agung III tidak dapat sepenuhnya mengikat masyarakat Bali selama hasil keputusan ini dimasukan kedalam awigawig yang mengatur masalah pewarisan pada setiap desa pakraman. Tetapi di beberapa desa pakraman sudah menerapkan hasil Keputusan Pesamuhan Agung III, hanya saja di desa pakraman yang hukum adanya masih begitu kental enggan untuk mengikuti peraturan baru yang telah disiarkan dari media sosial, acara televisi ataupun dari surat kabar. Jadi dalam Hasil Keputusan Pesamuhan Agung III kedudukan wanita dapat mewaris jika status wanita itu tinggal di rumah keluarga tersebut ataupun dia mengubah status menjadi sentana. Dengan persamaan kedudukan wanita dengan laki-laki, wanita berhak mewaris sebagai anak kandung maupun anak angkat berhak atas harta guna kaya orang tuanya setelah dibagi sepertiga sebagai harta bersama atau due tengah yang dikuasai bukan dimiliki oleh anak yang melanjutkan orang tuanya.

\section{Simpulan}

Dari uraian bab-bab sebelumnya maka dapat ditarik kesimpulan, Kedudukan wanita Bali dalam pewarisan dimana di Bali dalam sistemnya menganut sistem kekeluargaan patrilinial, dikatakan dalam hukum adat waris Bali wanita tidak dapat mewaris atau menjadi ahli waris karena dianggap wanita kurang pantas mewaris karena kewajiban yang ditanggung sangat berat, sesuai dengan kewajiban seorang wanita terhadap orang tuanya dan kepercayaannya di masyarakat. Dalam hukum adat waris Bali wanita dapat mewaris apabila telah merubah status perkawinannya menjadi purusa sesuai pada perkawinan nyeburin. Lain halnya dengan perempuan sebagai istri mempunyai kedudukan hukum dalam lingkungan keluarga suaminya.

Kedudukan wanita Bali setelah dikeluarkannya Keputusan Pesamuhan Agung III MUDP Bali merupakan sebuah jalan yang baik untuk memperkuat hukum adat waris Bali yang sudah lama berlaku dimasyarakat Bali yang dimana mendiskriminasi wanita akan tidak berhaknya mewaris. Waulupun dalam masyarakat Bali merupakan polemik yang pro dan kontra, dengan adanya keputusan Pesamuhan III MUDP Bali (Nomor 01/KEP/ PSM-3/MDP-BALI/X/2010) ini kedudukan wanita dalam keluarganya mengenai mewaris jadi wanita dapat mewaris dalam keluarganya atau menjadi ahli waris. Jadi pada umumnya pembagian waris untuk wanita dapat dilakukan jika wanita itu tidak kawin keluar atau ninggalin kedaton. Dan a pabila wanita tersebut kawin keluar, wanita dikatakan ninggalin kedaton batas, yang dimana ninggal kadaton tetapi dalam batas tertentu masih memungkinkan melaksanakan swadharma sebagai umat Hindu, maka warisannya juga masih dapat di terima dan diberikan oleh orang tuanya. Karena kodrat wanita memang harus keluar tetapi wanita tidak akan pernah lupa akan kewajibannya dalam ikut serta menjaga orang tuanya, dan merawatnya walaupun wanita itu sudah ikut dikerabat suaminya.

Dari pembahasan mengenai kedudukan wanita dalam mewaris dikeluarganya maka saran yang dapat diberikan yakni Untuk beberapa daerah di Bali masih tetap menggunakan awig-awig sistem pewarisan yang dari dulu, seharusnya MUDP Bali lebih tegas menetapkan Keputusan Pesamuhan Agung III ini untuk memasukan keputusan ini disetiap awig-awig sistem pewarisan yang ada di Desa Pakraman Bali. Agar persamaan kedudukan antara laki-laki dan wanita terasa adil.

Para orang tua dalam tatanan masyarakat di Bali ada baiknya untuk menerima keputusan yang telah dikeluarkan oleh MUDP agar dirasa keadilannya dalam pembagian warisan dalam sebuah keluarga. Walaupun kodrat wanita harus keluar tetapi wanita tidaklupa akan kewajibanny, maka wanita juga berhak atas haknya mewaris.

Bagi kaum wanita Bali dengan adanya kebaikan dari keluarnya Keputusan Pesamuhan Agung III tersebut, agar wanita lebih sadar akan kewajibannya dan tidak hanya menekankan haknya terhadap warisan yang diberikan oleh keluarganya melainkan juga dengan kewajibannya yang harus diterima seteah diterimanya hak mewaris tersebut. 


\section{Daftar Pustaka}

Arta, I. K. K., Sudiatmaka, K., \& Windari, R. A. (2018). Realisasi Keputusan Pesamuhan Agung III MUDP Bali terhadap Pewarisan Anak Perempuan Bali Aga di Kabupaten Buleleng. EJournal Komunitas Yustitia Universitas Pendidikan Ganesha, 1(1). Retrieved from http://dx.doi.org/10.23887/ jatayu.v1i1.28658

Artadi, I. K. (2017). Hukum Adat Bali. Bali: Bali Pustaka Post.

Muhammad, B. (2006). Pokok-Pokok Hukum Adat. Jakarta: Pradnya Paramitha.

Panetje, G. (1995). Catatan Tentang Hukum Adat Bali. Denpasar: CV Kayu Mas Agung.

Rato, D. (2015). Hukum Perkawinan Dan Waris Adat Di Indonesia. Yogyakarta: LaksBang PERSSindo.

Utari, N. K. S. (2008). Mengikis Ketidakadilan Gender Dalam Adat Bali. Jurnal Studi Jender Srikandi, 7(1). Retrieved from https://ojs.unud.ac.id/index.php/ srikandi/article/view/2893 